\author{
Alexandra Tieanu \\ Romania \\ Faculty of History and Philoshopy, Babes- Balyai University Cluj- Napoca, Romania
}

\title{
Euro- centrism vs International Thinking
}

Today, at every corner we find the same question in different forms: should we think only of Europe or we should remember that Europe is just one part of the world? This essay is meant to discuss the meaning of euro-centrism and how it is conceived nowadays. But living in a complex and inter-connected world we also have to take into consideration all the other elements: different cultures and civilizations, different economic powers and different mentalities. This is probably the best way to understand the reality we are living in.

Euro-centrism could be defined as the practice that takes into account Europe as a continent, the European culture, traditions, and civilization - all that matters is belonging to the European identity. This is one of the most frequent elements that influenced the mentality of this continent starting with early times and going on up to now (today, the tendency of all the states in Europe is to integrate into the European Union, the common symbol that everyone understands).

This mentality of the common European is in part born because every man sees himself as part of the place where he was born; but it is also created. It is created by the history and philosophy he learned in school, by his interaction with others, by the things he watches on TV, by the things he reads in books and so on. Firstly, history usually presents the events from Europe, starting with the Greeks and Romans and onwards to the present. In all the cases there is "us" and "them": the Christians and the pagans, the barbarians, creating, thus, a stereotype. For example, we learn about the Ccrusades: there are us, the Christians, as a whole (we can say the whole Europe) and there is them, the Muslims (Arabs, Turks, etc.), but the accent is on the Christians. Only if we go deep into the essence of things we will learn about the Muslims and their culture. Also, there is little interest for the ancient non-European empires, like the Chinese empire, the Indian Empire or the Empires from South America; but everyone knows about Rome. Secondly, the first steps in science are recognised as belonging to the Europeans but few are interested to know that scholars from the Far East have come to the same conclusions years before. Like in mathematics, everyone talks about Isaac Newton and Leibniz, but the Chinese had, from ancient times, methods and systems of calculus. Thirdly, philosophy studies Aristotle, Plato, Augustine, Kant, and so on, but there is a diminished accent put on Confucian or Islamic philosophy although they are as old and as interesting as the European. Fourthly, the practice and mental representations of the world, starting from Antiquity, are all about Europe and how Europe is in the centre of the world. Before the discoveries of the Americas, Africa and of the Orient, the Europeans thought there was only their continent. After seeing that there were others in the world, they saw themselves as the centre and all the others as barbarians that needed to be civilised. Fifthly, most of the things we see or read are about Europe and its people; we can find only limited information that we can access about the other parts of the continent. So, if we want to learn more about a certain culture or a certain people we have no choice, but going to that country.

It is important, I think, to talk about diversity and self-image. As European nations, we see ourselves as better than the others and tend to discriminate. This is seen especially in these last years (after September 11, 2001, to be specific). This is not the correct attitude we should take. We should try to understand the differences that exist in the other cultures and admit that every 
culture has its own malign elements. It is universally known that people tend to fear what they don't know, what they don't control. When it comes to knowing other cultures, most people see only the differences but do nothing to understand why the others are different and what is good about their culture. People usually just choose to ignore the others because they don't know anything about their culture but they could make an effort to understand them. Also, there should be less discrimination. Just because they are different it doesn't mean that they are not human or that they don't have feelings. It's just our opinion and we can tend to let ourselves be influenced by old-fashioned stereotypes, a thing that should make us think, should make us want to be better persons. For example, if one sees an Arab in the street, he first asks himself what country could he come from and if he is aggressive, rather than think about the Islamic religion and culture throughout history and what they had given to humanity.

However, we must not forget that we live at the beginning of the $21^{\mathrm{ST}}$ century and our mentality has evolved in the last hundred years (as it should have). In an age of communication and technology, in an age when everyone can contact everyone, we cannot ignore the rest of the world. Everyday we touch, eat, drink, wear and buy things that are made all over the world by people of different cultures, religions, languages and races. We cannot say that we are from Europe; we should say that we are from Earth. Yes, we are European, but we are all humans and equal and belonging to the same world. We define ourselves by relating to the rest of the world, to the different cultures, religions, languages, and races. In order to understand who we are, we should first understand the world we live in.

We live in a global world, that's the truth. There are multinational corporations that have offices all around the globe; there are universities that have academic connections with other universities from other continents; everyday we hear on the news what happened that day in the world, no matter that it is a carnival in Brazil, a bombing somewhere in an Islamic country, a civil war in the middle of Africa or a car crash in France. All events are equally important and everyone hears about them. Nowadays it doesn't matter only what happens in Europe, all that happens in the world matters because everything is connected to everything and anything can influence something. It is, therefore, important to learn even the smallest thing we can about other cultures and realise the fact that we are not alone in this world. We have to admit the fact that each culture has its own characteristics and they all create the same world, and we live in it.

The European Union has within its borders different cultures, different traditions and many mentalities. But the European Union must never forget that all these cultures have to work together so that they could be strong as one. All member states define themselves as European but through this they admit the existence of all the other cultures because in an identity definition a comparison is needed. So, it is generally admitted that the world has different elements but they all work together and this is seen especially at the economic level. In trade and finances it doesn't matter much what country you are from or what religion you have, only if you have enough resources to compete. Also, in cases of natural disasters in a country, it doesn't really matter what nationality is the man or woman that comes to help; all that matters is the solidarity.

In conclusion, I think being European is a part of every person that is born on this great continent, but that no one should ignore the fact that he belongs to a wider assembly: the world. Before judging or blaming anyone, we should make an effort to understand the entire mechanism of our world. This is not complicated: we just need to open our minds and find out a few things about the cultures that surround us. This is the first step. Then all we have to do is to see everyone as our friends and do not think that they are bad or lesser persons just because someone from an old, forgotten time had a bad experience. We are all part of the same universe in the end. 